\title{
PENGEMBANGAN MEDIA FLASHCARD PADA MATERI TATA SURYA KELAS VII DI MTSN 11 JOMBANG
}

\author{
Nur Izzatun Nikmah \\ Pendidikan IPA, Fakultas Ilmu Pendidikan, Universitas Hasyim Asy’ari \\ izzanun@gmail.com \\ Andri Wahyu Wijayadi \\ Pendidikan IPA, Fakultas Ilmu Pendidikan, Universitas Hasyim Asy'ari \\ diaandri@gmail.com
}

\begin{abstract}
Abstrak
Penelitian ini bertujuan untuk mendeskripsikan proses pengembangan media flashcard pada materi tata surya kelas VII di MTsN 11 Jombang berdasarkan prosedur pengembangan ADDIE dan mendeskripsikan produk hasil pengembangan setelah proses validasi. Penelitian pengembangan ini menggunakan model pengembangan ADDIE, yaitu Analisis, Rancangan, Pengembangan, Implementasi, dan Evaluasi. Penelitian pengembangan yang dilakukan tanpa adanya tahap implementasi dikarenakan pandemi Covid-19. Data hasil penelitian yang diperoleh dianalisis secara deskriptif kuantitatif. Hasil pengembangan media flashcard pada materi tata surya kelas VII di MTsN 11 Jombang setelah proses validasi diperoleh kriteria sangat valid dengan persentase $95,4 \%$. Berdasarkan hasil uji validitas media flashcard ini valid digunakan dalam proses pembelajaran.
\end{abstract}

Kata kunci: Media Flashcard, Model ADDIE, Tata Surya

\begin{abstract}
The purpose of this research is to describe the process of development flashcard media for class VII solar system materials at MTsN 11 Jombang based on the ADDIE development procedure and to describe the product development after the validation process. The development research used ADDIE development model, namely Analyzes, Design, Development, Implementation, and Evaluation. The Development research was carried out without an implementation stage, due to the Covid-19 pandemic. The data obtained were analyzed by descriptive quantitative. The results of the development of flashcard media for class VII solar system material at MTsN 11 Jombang after the validation process by the validator obtained very valid criteria with a percentage of $95.4 \%$. Based on the results of the validity test of the flashcard media, it was valid to be used in learning process.
\end{abstract}

Keywords: Flashcard Media, ADDIE Model, Solar System

\section{PENDAHULUAN}

Pembelajaran adalah proses interaksi antara peserta didik dengan guru dan sumber belajar di suatu lingkungan belajar (Widiasworo, 2018: 16). Pembelajaran bisa dilakukan di kelas maupun di luar kelas, dengan sumber belajar yang sudah dipersiapkan sebelumnya, seperti buku sekolah dan media pembelajaran lainnya. Pembelajaran di sekolah harus terprogram yang sesuai dengan kurikulum pendidikan, dengan urutan pembelajaran mulai dari perencanaan, pelaksanaan sampai penilaian. Pembelajaran yang terprogram membuat peserta didik mencapai tujuan pembelajaran yang sudah ditetapkan.

Pembelajaran Ilmu Pengetahuan Alam (IPA) pada dasarnya selalu berkaitan dengan kehidupan sehari-hari yang bermanfaat bagi peserta didik. Materi IPA setiap tingkatannya memiliki materi yang berbeda-beda. Tata surya merupakan salah satu materi IPA di SMP. Materi tata surya dipilih karena karakteristik materi tata surya dapat dipelajari secara visual atau dengan bantuan ilustrasi dan gambar. Pada materi tata surya terdapat cakupan materi yang luas, yaitu berupa teori dan hafalan, tanpa 
adanya materi yang berhubungan dengan hitungan. Kompetensi Dasar yang digunakan, yakni KD. 3.11 tentang materi tata surya.

Berdasarkan hasil wawancara dengan guru IPA di MTsN 11 Jombang pada tanggal 18 Oktober 2020, diperoleh informasi bahwa materi yang berhubungan dengan teori dan hafalan kurang diminati oleh peserta didik. Materi tersebut seperti, materi tata surya yang kebanyakan teori dan hafalan, serta tidak adanya materi hitungan. Penerapan pembelajaran IPA pada materi tata surya guru jarang menggunakan media pembelajaran. Media pembelajaran berupa poster dan alat peraga dari tahun ke tahun masih digunakan dalam proses pembelajaran, dikarenakan belum adanya media pembelajaran lainnya.

Hasil penyebaran angket pada peserta didik menyatakan bahwa guru mengajar di depan kelas $51 \%$. Media pembelajaran yang sering digunkan guru adalah papan tulis 44\%. Peserta didik menganggap pembelajaran IPA kurang menyenangkan $41 \%$. Media pembelajaran yang membantu peserta didik memahami materi pembelajaran adalah gambar dan tulisan $69 \%$. Materi tata surya memiliki cakupan sub materi yang luas $58 \%$.

Permasalahan yang ditemukan dalam pernyataan diatas yaitu, peserta didik kurang aktif dan kurang bersemangat dalam proses pembelajaran. Pada penerapan pembelajaran guru sering menjelaskan di depan kelas dan menyebabkan proses pembelajaran tidak menyenangkan. Bunyi Permendikbud No. 22 tahun 2016, bahwa peserta didik seharusnya mengikuti proses pembelajaran yang menyenangkan, inspiratif, interaktif dan menantang supaya memotivasi proses belajar peserta didik. Proses pembelajaran yang menyenangkan membuat peserta didik lebih aktif dan lebih bersemangat dengan menggunakan media pembelajaran (Rohmatin, 2017: 303).
Media pembelajaran merupakan sarana atau peralatan yang digunakan untuk menyampaikan pesan (Zaman \& Hernawan, 2019: 7). Pesan yang disampaikan dapat diterima melalui pikiran, perasaan, dan kemampuan peserta didik, sehingga akan mendorong terjadinya proses pembelajaran. Penggunaan media pembelajaran harus disesuaikan dengan konsep pembelajaran, maka guru harus mampu mengembangkan media pembelajaran yang efektif. Harapan penggunaan media pembelajaran mampu membuat perubahan-perubahan perilaku peserta didik berupa kemampuankemampuan baik dalam hal pengetahuan, sikap maupun keterampilan (Zaman \& Hernawan, 2019: 4). Media pembelajaran digolongkan tiga jenis, yaitu media audiovisual seperti: program televisi, media audio seperti: program radio, dan media visual seperti: kartun dan flashcard (Zaman \& Hernawan, 2019: 22).

Media pembelajaran yang dapat memfasilitasi pengembangan tersebut adalah flashcard. Flashcard adalah media visual berbentuk kartu kecil berisikan teks, simbol ataupun gambar yang mengingatkan atau mengarahkan peserta didik kepada sesuatu yang berhubungan dengan kata-kata dan gambar (Arsyad, 2014: 115). Ukuran media flashcard disesuaikan dengan kebutuhan kelas yang dihadapi. Media flashcard dibuat semenarik mungkin dengan dilengkapi petunjuk penggunaannya, agar peserta didik dalam memainkannya tanpa kesulitan dan mampu membantu peserta didik memahami materi dengan baik (Setyawan, 2019: 261). Keunggulan media flashcard, yaitu ukurannya tidak terlalu besar, praktis dan mudah digunakan, pesan dalam media flashcard mudah diingat, serta bisa digunakan dalam bentuk permainan (Indriana, 2011: 69).

Model pengembangan yang dapat digunakan dalam pengembangan media 
flashcard yaitu, model pengembangan ADDIE. Model ini ada lima tahap, antara lain: Analyze (analisis), Design (rancangan), Development (pengembangan), Implementation (implementasi), and Evaluation (evaluasi). Kelebihan model ini, yakni model pengembangan yang tersusun dengan cara terprogram berdasarkan urutan kegiatan yang sistematis. Model pengembangan ADDIE terdapat tahap evaluasi yang memberikan kesempatan melaksanakan kegiatan evaluasi terhadap setiap tahapannya. Pengaruh positif terhadap evaluasi disetiap tahap dapat mengurangi kekurangan produk pada tahap akhir (Tegeh, et al, 2014: 41).

Penelitian pengembangan tentang flashcard cocok digunakan pada materi IPA, diantaranya telah dilakukan oleh: (a) penelitian oleh Setyawan (2019) dengan penelitian pengembangan media flashcard berbasis pictorial riddle pada materi Plantae. Hasil penelitian pengembangannya teruji valid,

(b) penelitian oleh
Damayanti, et al, (2016) dengan penelitian pengembangan media visual flashcard pada materi Interaksi Makhluk Hidup dengan Lingkungannya. Hasil penelitian pengembangannya teruji valid, dan (c) penelitian oleh Rohmatin (2017) dengan penelitian pengembangan flashcard pada materi Sistem Gerak Manusia. Hasil penelitian pengembangannya teruji valid.

Berdasarkan permasalahan di atas, maka telah dilakukan penelitian dengan judul "Pengembangan Media Flashcard pada Materi Tata Surya Kelas VII di MTsN 11 Jombang".

\section{METODE}

Penelitian pengembangan ini menggunakan model pengembangan ADDIE (Analyze, Design, Development, Implementation, and Evaluation). Namun, karena adanya pandemi Covid-19 tidak memungkinkan melaksanakan Implementation. Diagram alir penelitian pengembangannya sebagai berikut.

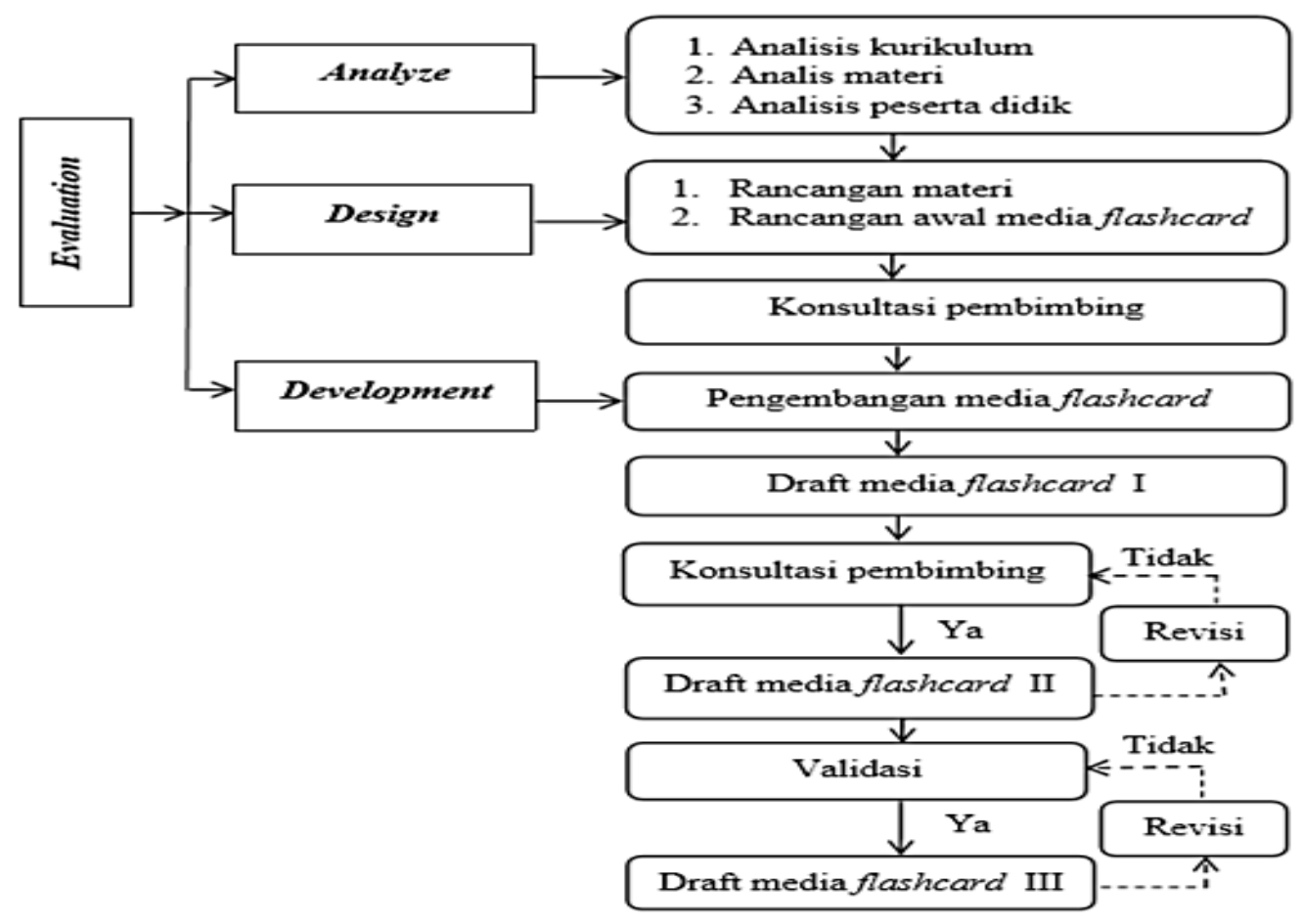

Gambar 1. Diagram Alir Penelitian 
Pertama, (analyze) terdiri dari analisis kurikulum, analisis materi, dan analisis peserta didik. Analisis kurikulum bertujuan untuk mengetahui pengunaan kurikulum yang digunakan di sekolah. Analisis materi dilakukan dengan cara mengidentifikasi, mengumpulkan, dan memilih materi yang relevan berdasarkan Kompetensi Dasar dan indikator pembelajaran. Analisis peserta didik bertujuan untuk mengetahui perbedaan karakteristik peserta didik. Analisis ini dilakukan agar pengembangan media flashcard dalam kegiatan pembelajaran dapat disesuaikan dengan kemampuan yang dimiliki peserta didik.

Kedua, (design) pengembangan media flashcard diuraikan dalam kegiatan sebagai berikut: (1) merancang materi yang akan digunakan dalam pengembangan media flashcard pada materi tata surya. (2) rancangan awal media flashcard pada materi tata surya dibuat berupa rancangan awal media flashcard dan rancangan awal box media flashcard. (3) mengkonsultasikan desain awal media flashcard pada dosen pembimbing.

Ketiga, (development) media flashcard dilakukan dengan menyusun draft media flashcard I pada materi tata surya. Berikut ini kegiatan pengembangan media flashcard yang dilakukan: (1) pengembangan media flashcard pada materi tata surya dibuat dengan tahapan: mengembangakan media flashcard dan box media flashcard yang menghasilkan draft media flashcard I. (2) konsultasi pembimbing mengenai draft media flashcard I untuk merevisi tahap awal pengembangan produk media flashcard. Sehingga, menghasilkan draft media flashcard II. (3) validasi draft media flashcard II dilakukan oleh validator (dosen ahli media dan dosen ahli materi dari Prodi Pendidikan IPA Universitas Hasyim Asy'ari dan guru IPA di MTsN 11 Jombang). Validasi oleh validator dilakukan dengan tujuan mendapatkan penilaian, saran dan masukkan sebagai bahan revisi terhadap media flashcard. (4) proses perbaikan (revisi) draft media flashcard II dilakukan sesuai dengan saran dan masukkan oleh validator. Sehingga, menghasilkan draft media flashcard III yang dapat dinyatakan valid oleh validator.

Keempat, (evaluation) produk media flashcard sebelum dinyatakan valid perlu adanya revisi. Sehingga, akan menghasilkan produk media flashcard yang dinyatakan valid.

Analisis data yang digunakan untuk mendapatakan hasil pengembangan media flashcard pada materi tata surya kelas VII di MTsN 11 Jombang yang memiliki kriteria valid. Data hasil penelitian yang diperoleh dari validator dianalisis secara deskriptif kuantitatif. Berikut langkahlangkah dalam menganalisis media flashcard yang telah dikembangkan: Skala penilaian media flashcard diperoleh menggunakan skala Likert, sebagai berikut:

Tabel 1. Kriteria Penilaian Media Flashcard

\begin{tabular}{|l|c|}
\hline \multicolumn{1}{|c|}{ Kriteria } & Skor \\
\hline Tidak Baik & 1 \\
\hline Kurang Baik & 2 \\
\hline Baik & 3 \\
\hline Sangat Baik & 4 \\
\hline
\end{tabular}

Rumus untuk menghitung persentase hasil validasi, yaitu:

Persentase $=\frac{\text { Skor yang diperoleh }}{\text { Skor maksimal }} \times 100 \%$

Persentase hasil validasi diinterpretasikan, sebagai berikut:

Tabel 2. Kriteria Validasi Media Flashcard

\begin{tabular}{|l|c|}
\hline \multicolumn{1}{|c|}{ Kriteria } & Persentase $(\boldsymbol{\%})$ \\
\hline Tidak Valid & $0 \leq \mathrm{x} \leq 20$ \\
\hline Kurang Valid & $20<\mathrm{x} \leq 40$ \\
\hline Cukup Valid & $40<\mathrm{x} \leq 60$ \\
\hline Valid & $60<\mathrm{x} \leq 80$ \\
\hline Sangat Valid & $80<\mathrm{x} \leq 100$ \\
\hline
\end{tabular}

(Sugiyono, 2019: 148) 


\section{HASIL DAN PEMBAHASAN}

\section{Proses Pengembangan Media Flashcard}

Penelitian pengembangan media flashcard pada materi tata surya kelas VII di MTsN 11 Jombang menggunakan model pengembangan ADDIE, yang terdiri dari tahap analisis, tahap rancangan, tahap pengembangan, dan tahap evaluasi.

Tahap analisis, yang dimulai dengan analisis kurikulum didapat bahwa Kurikulum 2013 dengan KD. 3. 11 tentang tata surya yang digunakan dalam pengembangan media flashcard. Selanjutnya, analisis materi yang hasilnya adalah materi tata surya dipilih karena memiliki cakupan materi yang luas dan tanpa adanya hitungan. Setelah itu, analisis peserta didik dengan hasilnya dapat diketahui dalam data rekapitulasi hasil penyebaran angket yang menunjukkan bahwa penggunaan media flashcard dalam proses pembelajaran sangat menyenangkan. Hal ini didukung dengan penelitian (Wardiah \& Lepiana: 2018) bahwa penggunaan media flashcard sangat memotivasi peserta didik, sehingga proses pembelajaran akan menyenangkan.

Tahap rancangan, yang menghasilkan rancangan materi dan rancangan produk awal media flashcard dan box media flashcard. Rancangan materi dibuat dengan mengumpulkan referensi materi tata surya, seperti buku tentang Bumi dan Tata Surya oleh Danang (2017). Hasil rancangan produk awal media flashcard, dan box media flashcard berupa:

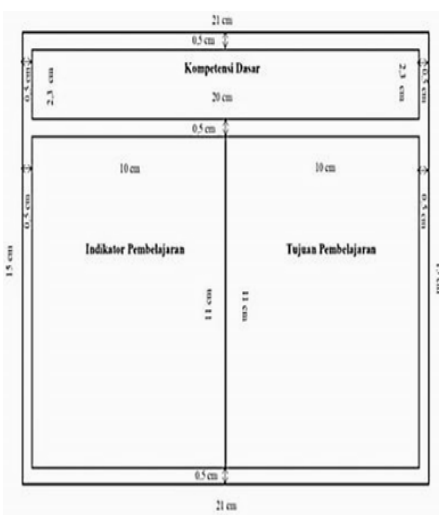

(a)

Rancangan Kompetensi Dasar, Indikator Pembelajaran, dan Tujuan Pembelajaran

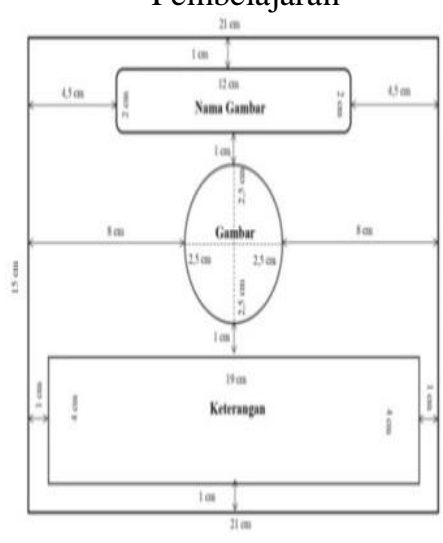

(d)

Rancangan media flashcard

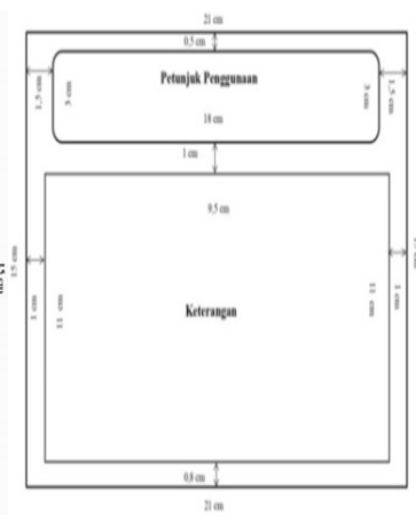

(b)

Rancangan petunjuk penggunaan media flashcard

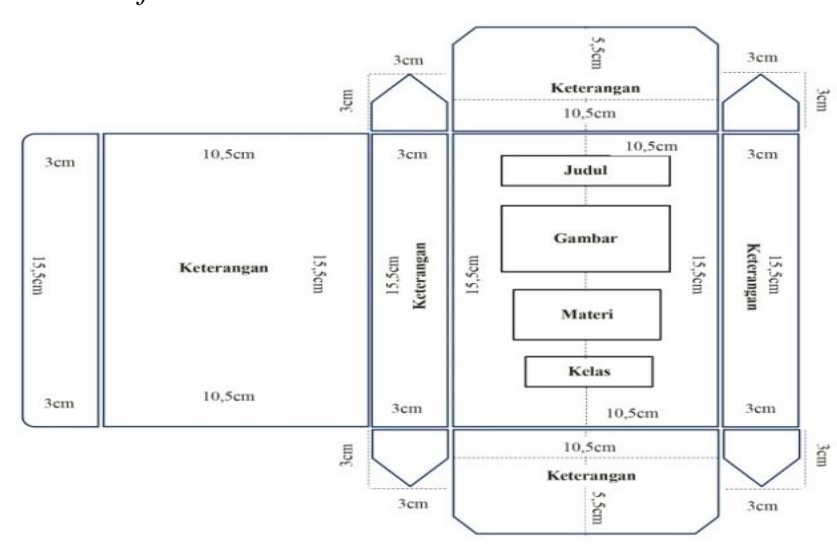

(e)

Gambar 2. Rancangan Awal Media Flashcard dan Box Media Flashcard 
Pada tahap ini rancangan yang dibuat sebelumnya dikonsultasikan kepada dosen pembimbing untuk penyempurnaan rancangan materi dan produk yang akan dikembangkan pada tahap selanjutnya..

Tahap pengembangan hasilnya berupa draft media flashcard I, serta saran dan masukan dari dosen pembimbing terhadap draft media flashcard I, yang menghasilkan draft media flashcard II. Draft media flashcard II digunakan untuk mendapatkan saran dan masukan dari validator, yang menghasilkan draft media flashcard III. Hasil pengembangan media flashcard dapat dilihat sebagai berikut:

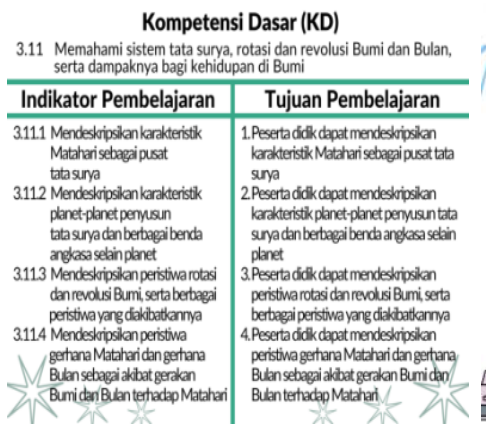

(a)

Pengembangan Kompetensi Dasar, Indikator Pembelajaran, dan Tujuan Pembelajaran

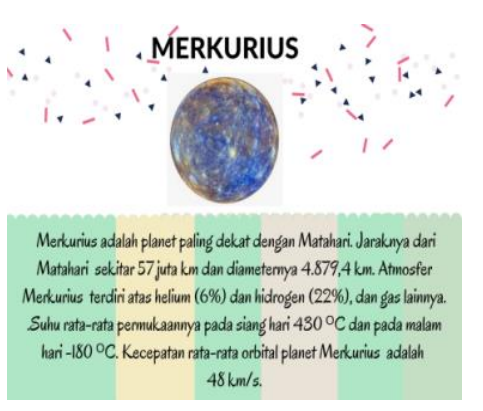

(d)

Pengembangan media flashcard

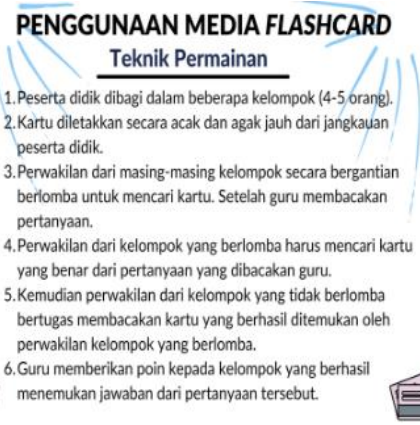

(b)

Pengembangan petunjuk penggunaan media flashcard

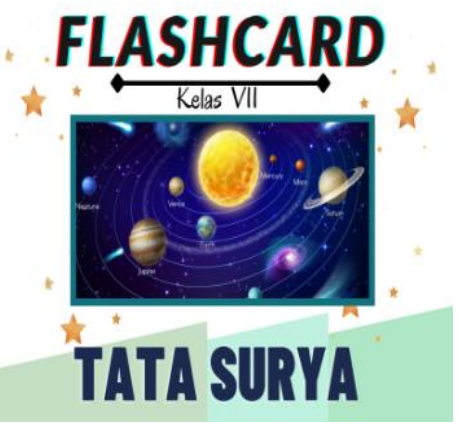

(c)

Pengembangan cover media flashcard

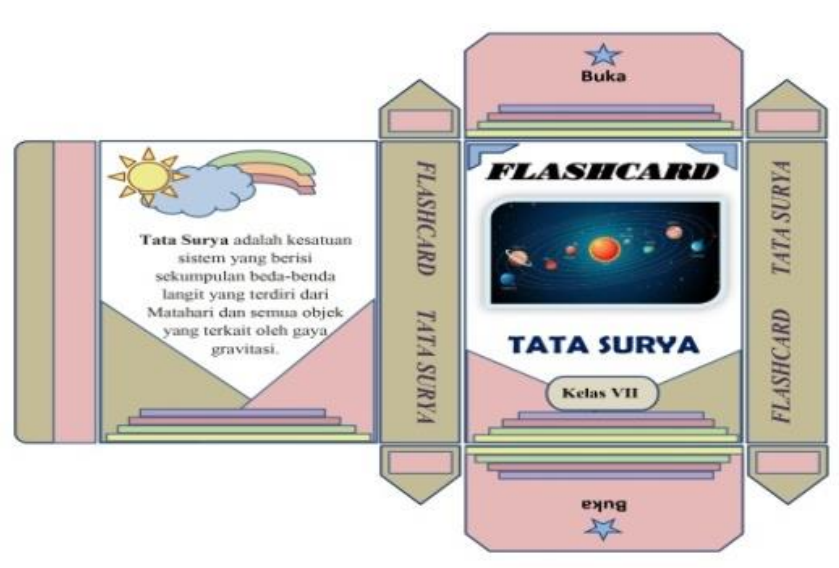

(e)

Gambar 3. Pengembangan Media Flashcard dan Box Media Flashcard

Tahap evaluasi dilakukan dari tahap analisis, rancangan, dan pengembangan. Evaluasi yang dilakukan selalu memperhatikan saran dan masukan dari dosen pembimbing dan validator untuk mengetahui seberapa valid dan kurang validnya media flashcard yang telah dikembangkan dari aspek kevalidan. Hasil akhir evaluasi media flashcard yang telah divalidasi oleh validator dinyatakan sangat valid.

\section{Kualitas Media Flashcard}

Hasil penelitian pengembangan memperoleh data berupa validasi media flashcard yang dilakukan oleh validator. Rekapitulasi hasil validasi media flashcard adalah. 
Tabel 3. Rekapitulasi Haasil Validasi Media Flashcard

\begin{tabular}{|c|c|c|c|c|c|c|}
\hline \multirow{2}{*}{ No } & \multirow{2}{*}{ Aspek yang divalidsi } & \multicolumn{3}{|c|}{ Skor } & \multirow{2}{*}{$\begin{array}{c}\text { Persentase } \\
(\%)\end{array}$} & \multirow{2}{*}{ Kriteria } \\
\hline & & V1 & $\mathbf{V 2}$ & V3 & & \\
\hline \multicolumn{7}{|c|}{ Kualitas Materi } \\
\hline $\mathrm{I}$ & Kelengkapan Materi & 4 & 3 & 4 & 91,7 & Sangat Valid \\
\hline II & Kebahasaan Materi & 4 & 4 & 3 & 91,7 & Sangat Valid \\
\hline III & Penyajian Materi & 4 & 4 & 4 & 100 & Sangat Valid \\
\hline \multicolumn{7}{|c|}{ Kualitas Intruksional } \\
\hline I & Petunjuk Penggunaan & 4 & 4 & 4 & 100 & Sangat Valid \\
\hline II & Keterbacaan & 4 & 4 & 4 & 100 & Sangat Valid \\
\hline \multicolumn{7}{|c|}{ Kualitas Teknis } \\
\hline I & Penggunaan Media & 3 & 4 & 4 & 91,7 & Sangat Valid \\
\hline II & Tampilan Media & 4 & 3 & 4 & 91,7 & Sangat Valid \\
\hline III & Tampilan Pengemasan & 3 & 4 & 4 & 91,7 & Sangat Valid \\
\hline \multicolumn{7}{|c|}{ Karakteristik Media } \\
\hline $\mathrm{I}$ & Karakteristik Media Flashcard & 4 & 4 & 4 & 100 & Sangat Valid \\
\hline \multicolumn{5}{|c|}{ Persentase Hasil Validasi (\%) } & 95,4 & Sangat Valid \\
\hline
\end{tabular}

Berdasarkan hasil validasi media flashcard oleh validator, data hasil validasi tersebut mendapat persentase $95,4 \%$, dengan kriteria Sangat Valid.

\section{SIMPULAN}

$\begin{array}{ccc}\text { Berdasarkan } & \text { hasil } & \text { penelitian } \\ \text { pengembangan } & \text { yang } & \text { dilakukan }\end{array}$ simpulannya sebagai berikut: Penelitian ini merupakan jenis penelitian pengembangan dengan menggunakan model

\section{DAFTAR PUSTAKA}

Arsyad, A. 2014. Media Pembelajaran. Jakarta: Rajawali Pers.

Damayanti, E., Yunus, S.R., \& Sudarto. 2016. Pengembangan Media Visual Flashcard pada Materi Interaksi Makhluk Hidup dengan Lingkungannya. Jurnal Sainsmat, Vol. 5, No. 2, 175-182.

Danang. 2017. Bumi dan Tata Surya. Solo: Azka Pressindo.

Rohmatin, D.N. 2017. Pengembangan Flashcard pada Materi Sistem Gerak Manusia untuk Meningkatkan Hasil Belajar Siswa di Kelas VIII SMP. Jurnal Pendidikan Sains, Vol. 5, No. 03, 303-307.

Setyawan, P. 2019. Pengembangan Media Flashcard Berbasis Pictorial Riddle Pada Materi Plantae untuk pengembangan ADDIE (Analyze, Design, Development, and Evaluation) yang menghasilkan produk media flashcard pada materi tata surya kelas VII di MTsN 11 Jombang. Media flashcard layak digunakan sebagai media pembelajaran pada materi tata surya berdasarkan hasil validasi terhadap media flashcard dengan kriteria sangat valid yang memperoleh persentase sebesar $95,4 \%$.

Meningkatkan Motivasi dan Pemahaman Konsep Siswa SMA/MA Kelas X. Journal Berkala Ilmiah Pendidikan Biologi, Vol. 8 No. 2, 260269.

Sugiyono. 2019. Metode Penelitian Kuantitatif, Kualitatif, dan $R \& D$. Bandung: Alfabeta.

Tegeh, M., Jampe, N., \& Pudjawan, K. 2014. Model Penelitian Pengembangan. Yogyakarta: Graha Ilmu.

Widiasworo, E. 2018. Strategi Pembelajaran Edutainment Berbasis Karakter. Yogyakarta: AR-Ruzz Media.

Zaman, B. \& Hernawan, A.H. 2019. Media \& Sumber Belajar Paud. Banten: Universitas Terbuka. 